\title{
STUDIES ON SUBSTITUTING GRADED LEVELS OF FERMENTED FISH BYPRODUCTS ON GROWTH PERFORMANCE AND HEALTH STATUS OF NILE TILAPIA FINGERLINGS. \\ Gouda, A.H. ${ }^{1}$; A.E. Tolan ${ }^{1}$ and W.T. El -Ekiaby ${ }^{2}$ \\ Fish Nutrition $^{1}$ and Fish Health and Management Departments, ${ }^{2}$ \\ Central Laboratory for Aquaculture Research, Abbasa, Sharkia, A.R.E..
}

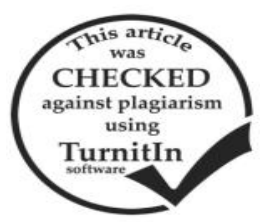

\section{ABSTRACT}

This study aimed to evaluate replacing fish meal with graded levels of silage made from fish by-products to feed monosex males of Nile tilapia (Oreochromis niloticus). Three diets were formulated in which fish meal was replaced by fish silage $(0,25,50,75$, and $100 \%)$. Diets were fed to experimental groups of tilapia for 120 days. The highest total weight gain TWG (49.93 g) was recorded for fish fed the control diet (SFB0) followed by those fed the diet SFB25\% (44.01g/fish), SFB50\% (43.08g/fish), SFB75\% (38.65g/fish) and SFB100\% (36.38g/fish), respectively and the differences in weight gain among the different fingerling groups were significant $(\mathrm{P}>0.05)$. Moreover, the same observation was noticed for specific growth rate SGR. In addition to that, the average feed intake and feed conversion ratio and protein efficiency ratio of Nile tilapia were significantly $(\mathrm{P}<0.05)$ affected by the incorporation of fermented fish meal as a substitute of fish meal. The carcass composition parameters of body composition was significantly altered while no significant differences were found among all studied groups concerning the moisture content.

Replacing up to $75 \%$ of FM by SFB neither affected growth performance nor health state of tilapia but, economically decreased costs of production. Even though replacing up to $(100 \%)$ was economically favored and gave good growth performance but it was a source of parastic infestation adversely affecting the health condition of tilapia and was cosmopolitan rendering fish esthetically unaccepted for human consumption.

\section{INTRODUCTION}

Regarding the importance of proper nutrition and cost-effective inconvenient ration for fish, there are needs for research effort to evaluate the nutritive value of different animal and plant by-products as feed staff in fish diet to replace some components as fishmeal, which is expensive and gradually becoming scarce (Bairagi et al. 2012). Fish silage has been used as a feed supplement for various livestock animals and poultry and results have generally shown that it has good nutritional quality. The biological value of its protein was also comparable with that of fish meal protein (Yegorov et al. 2013). However, only recently has its potential in aquaculture diets been recognized, hence few studies have assessed its suitability. Generally, fish silage has been compared with fish meal and its suitability assessed by fish growth responses, protein utilization and digestibility. Conflicting results have been reported on fish silage as fish meal replacer (either partially or totally) in fish diets. Using fish by-products as alternative source of animal protein for fish and other animal diets is gaining importance because it produces both environmental benefits and reduces the costs of animal production (Hammoumi et al., 2008 and Rangacharyulu et al, 2013). Fish offal, (FO) are useful as fish feed even though sometimes thrown in bulk in some small local fish markets, these byproducts contain high amounts of crude protein (30-32\%) and lipid (15-18\%). Fermented fish-offal has been proved to be a viable source of protein for feeding carps (Esteban et al., 2007)

However, FO needs to be processed properly before using it for ration formulation. Fermentation has been proved to be the most suitable technique for improving nutritional quality of animal byproducts (Mondal et al., 2007, Bairagi et al, 2012 and Nwana, 2013).
Silage production can come from two techniques; chemical acidification (acid preserved silage) or bacterial fermentation (fermented silage).To undergo proper fermentation, the raw material must contain lactic acid bacteria, a suitable nutritional substrate for the bacteria within suitable temperature compatible for rapid growth and propagation of bacteria. Although lactic acid bacteria are already present in the raw material and could be a starter culture, it is recommended to add a starter for favorable nonpolluted growth (Kompiang et al., 1980b \& 1980).

Since the process might be opposed to spoilage bacteria a specific fermentable substrate is mixed with the minced raw material to be ensiled. Molasses added at a ratio of at least 1:10 (w/w) molasses to fish is particularly effective (Kompiang et al., 1980b and Raa and Gildberg, 1982). Under favorable conditions, the lactic acid produced reduces the $\mathrm{pH}$ of the silage, preserving it form spoilage and encouraging autolysis by naturally occurring protease enzymes. Preliminary feeding trials with fish indicated that fermented silages are nutritionally equivalent to fish meal (FAO, 1983). Storage properties of these acid preservation techniques of animal/carbohydrates silages are useful for both subtropical and tropical regions where conventional freezing techniques are expensive or not available (Soltan and Tharwat 2006) indicated that fermented fish silage can successfully replace up to 25 and $50 \%$ of fish meal in Nile tilapia, O. niloticus and African catfish, Claris gariepinus diets without adverse effect on growth performance or feed utilization. Therefore, the aim of this study is to evaluate feeding substituted graded levels of SFB for $O$. niloticus monosex males fingerling .

\section{MATERIALS AND METHODS}

The present study was done in the Central Laboratory of Aquaculture Research (Sakha unit). The practical work of the present experiment started on the $25^{\text {th }}$ of May 2015 and lasted to the $24^{\text {th }}$ of September 2015, to 
study the effect of replacement of fish meal by fish silage on growth performance, efficiency of feed utilization and economical efficiency of nile tilapia,

\section{1- The experimental design}

Fifteen rectangular aquaria $80 \times 30 \times 40 \mathrm{~cm}$ were filled each by about 70 liter of fresh dechlorinated tap water making five treatments ( 3 replicates for each treatment) and each aquarium was stocked with 15 monosex males of Nile tilapia fish fingerlings with an initial weight ranging between 5.77 and $5.88 \mathrm{~g} /$ fish, obtained from a private farm.

After acclimation (30 days) fish were randomly distributed into the experimental aquaria representing the five treatments with their replicates. The means of initial body weight $(\mathrm{BW})$ and body length $(\mathrm{BL})$ for each aquarium were recorded. About $25 \%$ of water volume in each aquarium was daily replaced by aerated fresh water after cleaning and removing the accumulated excreta. Dissolved oxygen was maintained by continuous aeration and water quality parameters were kept within acceptable limits for fish growth and health according to Boyd (1979).

\section{2-Preparation of fermented fish silage (SFB):}

Fish byproducts (non edible parts) were obtained from a fish local market then minced. The SFB was prepared by mixing the minced fish by-products $(60 \%)$ rice bran $(30 \%)$ as filler, dried molasses $(5 \%)$ as a source of carbohydrate (energy) and 5\% yogurt (as a source of Lactobacillus spp for lactic acid anaerobic fermentation process). Potassium sorbate solution (1\%) as antimicrobial agent was sprayed and the mixture was packed in black polyethylene bags. All bags were incubated in tightly hard plastic container within temperature about $34^{\circ} \mathrm{C}$. The ensilage process took 30 days to be completed. Finally a liquid SFB of $\mathrm{pH} 4.7$ was obtained and sun-dried for 3 days. The resultant dried SFB had brownish color and strong fishy odor (Mondal et al., 2007).

\section{3-Diet preparation}

Five diets were prepared by thoroughly mixing the ingredients which composed of fish meal $21 \%$, soybean meal, fermented fish silage $(5.25 \%, 10.75 \%$, $10.5 \%, 5.25$ and $21 \%$ ), yellow corn $(28.7,30 \%$, ) and vegetable oil $(3 \%)$, gluten $(5 \%)$ and rice bran $(12 \%)$ with different percentage (Table 1). Dry ingredients were first ground to small particles. Ingredients were mixed and then water was added to obtain a $30 \%$ moisture level. Diets were passed through a mincer machine of $2 \mathrm{~mm}$ diameter and were sun dried for 3 days. The experimental diets were formulated to replace $0,25,50,75$ and $100 \%$ of FM by SFB based on protein content. All diets were formulated to be isonitrogenous (35.32\% protein) and isocaloric (3600 $\mathrm{kcal} \mathrm{DE} / \mathrm{kg} \mathrm{diet})$.

\section{Table (1): Composition and chemical analysis of the experimental diets.}

\begin{tabular}{lccccc}
\hline Feed ingredients & Diet1 & Diet2 & $\begin{array}{c}\text { Experimental diets } \\
\text { Diet3 }\end{array}$ & Diet4 & Diet5 \\
\hline Fish meal (72\%) & 21 & 15.75 & 10.5 & 5.25 & 0 \\
Fermented fish silage (FFB) & 0 & 5.25 & 10.5 & 15.75 & 21 \\
Yellow corn & 28.7 & 28.2 & 25.7 & 26.7 & 27.7 \\
Soybean meal (44\%) & 30 & 31.5 & 35 & 35 & 35 \\
Gluten & 5 & 5 & 5 & 5 & 5 \\
Rice bran & 12 & 11 & 10 & 9 & 8 \\
Vegetable oil & 3 & 3 & 3 & 3 & 3 \\
Vit. \& Min. mixture1 & 0.3 & 0.3 & 0.3 & 0.3 & 0.3 \\
Total & 100 & 100 & 100 & 100 & 100 \\
DM & 98.23 & 97.32 & 98.17 & 98.20 & 97.80 \\
Crude protein (CP) & 35.35 & 35.32 & 35.32 & 35.32 & 35.32 \\
Ether extract (EE) & 8.39 & 8.48 & 8.56 & 8.40 & 8.33 \\
Crude fiber (CF) & 7.33 & 7.22 & 7.10 & 7.24 & 7.82 \\
Ash & 8.12 & 8.14 & 8.33 & 8.45 & 8.09 \\
NFE & 40.81 & 40.84 & 40.69 & 40.59 & 40.44 \\
GE cal/kg & 4444.1 & 4449.44 & 4450.79 & 4491.69 & 4425.54 \\
\hline (1)Relin
\end{tabular}

(1)Requirements are based on NRC (2011) values for tilapia.

Tilapia fish fed at a dialy rate of $10 \%$ (during the first and second month), then decreased to $5 \%$ (during the third and fourth months) of total biomass 6 day/week (twice daily at 8.00 am and $2.00 \mathrm{pm}$ ) and the amount of feed was bi-weekly adjusted according to the changes in body weight throughout the experimental period.

\section{4-Growth performance and feed utilization parameters}

Weight gain $=$ final weight $(\mathrm{g})-$ initial weight $(\mathrm{g})$

Daily weight gain $(\mathrm{DWG})=$ Weight gain

(g)/experimental Period

Specific growth rate $(\mathrm{SGR})=\frac{\operatorname{Ln} W 2-\operatorname{Ln} W 1}{t} \times 100$

Where $\mathrm{Ln}=$ the natural $\log , \mathrm{W}_{1}=$ first fish weight, $\mathrm{W}_{2}=$ the following fish weight in "grams" and $t=$ period in days.
Condition factor $(\mathrm{K})=\left(\mathrm{W} / \mathrm{L}^{3}\right) \times 100$ Where:-W = weight of fish in"grams",L=total length of fish in "cm"

Feed conversion ratio $(\mathrm{FCR})=$ Feed ingested $(\mathrm{g}) /$ Weight gain $(\mathrm{g})$ Protein efficiency ratio $(\mathrm{PER})=$ Weight gain (g)/Protein ingested (g)

\section{5- Proximate analysis}

Proximate analysis for experimental diets, and whole fish bodies were carried out for moisture, protein, ash, and fat according to the methods described by A.O.A.C. (1990). Nitrogen free extract and gross energy was calculated by differences.

\section{6- Statistical analysis}

Statistical analysis of the obtained data for the two experiments was done according to SAS (1996). Differences between means were tested for significance according to Duncan's multiple rang test 
as described by Duncan (1955). The following model was used to analyze the obtained data:

$$
\mathrm{Y}_{\mathrm{ij}}=\mu+\alpha \mathrm{i}+\mathrm{e}_{\mathrm{ij}}
$$

Where: $Y_{i j}=$ the observation on the $\mathrm{ij}^{\text {th }}$ fish eaten the $\mathrm{i}^{\text {th }}$ diet; $\mu=$ overall mean,

$\alpha_{i}=$ the effect of $i^{\text {th }}$ diet $E_{i j}=$ random error assumed to be independently and randomly distributed $\left(0, \delta^{2} \mathrm{e}\right)$.

\section{7-Clinical and postmortem examination of fish}

Five samples representation the five treatments of the collected fishes were examined using the methods described by Schaper-claüse, (1992) to investigate any lesions on the external body surface. Fishes were examined for skin darkening, discoloration, paleness, congestion, hemorrhages, erosions or ulcers and presence of eye cloudiness, ragged, torn fins or raised scales. Internally, The abdomen was examined for enlargement; distention, parasitic larvae or sunken eyes. Mouth and gills were examined for any abnormalities.

The postmortem examination was performed to examine internal organs of fishes according to Stoskopf (1993). The abdominal wall was removed and the internal organs were examined macro and microscopically for any abnormalities, gills, musculature and internal organs were examined for the presence of any visible cyst, larvae or worms. Fishes were grossly examined for detection of any external visible parasites on the body surface (skin, fins, gills, eye and mouth). Also, internal organs were examined by naked eyes, by magnifying hand lens and microscopically for any parasitic stages.

\section{8- Identification of the detected parasites:}

The identification of the detected parasites was carried out according to Lom and Dykova (1992) .

The obtained larval nematodes were washed in saline, stretched using hot alcohol glycerin 5\% and mounted in glycerin-gelatin according to Meyer and Olsen (1992). Worms in the fish flesh were recovered and counted using Smith and pepsin- $\mathrm{HCl}$ digest method (Berland) (1989). To identify the nematodes by light microscopy, they were fixed in hot $70 \%$ ethanol, cleared in glycerin and temporarily placed in mounts. Identification of the specimens was based on the morphology of the digestive tract, the position of the boring tooth in relation to the excretory pore and the morphology of the post anal tail.

\section{RESULTS AND DISCUSSION}

\section{1-Growth performance and feed utilization parameters Body weight (BW) and body length (BL):}

As described in Table (2), the highest average final BW (55.80) was recorded for control group which fed the basal diet (control). Replacing of $25 \%$ or $50 \%$ of fish meal (FM) by (SFB) in the diets SFB25\% and SFB50\% reduced the final BW to 49.83 and 48.90 $\mathrm{g} /$ fish but these values did not significantly differe from that fed the basal diet. Compared to fish fed the basal diet, the higher replacing levels of FM by FFB (75 or $100 \%$ ) in the diets FFB75\% and FFB $100 \%$ significantly $(\mathrm{P}<0.001)$ decreased the BW of Nile tilapia fish to 44.42 and $42.18 \mathrm{~g} /$ fish, respectively indicating the possibility of replacing $50 \%$ of FM in the basal diets of Nile tilapia fish by FFB without adverse effect on the final BW.

By ending the experiment, the highest average BL $(13.86 \mathrm{~cm})$ was recorded for fish group FFB50\% followed in a descending order by those fed the control diet, FFB0 (13.83 cm), FFB25\% (13.77), FFB75\% (13.33), and FFB100\% (13.14), respectively and the differences between fish groups were significant.

The highest average condition factor $(2.27,1.97)$ was recorded for fish group fed the diets FFB0 and FFB25\% ( 0 and $25 \%$ replacement of FM by FFB) followed in descending order by those fed the diet FFB50 (1.85), FFB75 (1.83), and FFB100\% (1.76) respectively. Results of Table 2 are in accordance with the results of Nwanna and Daramola (2001) and Bairagi et al (2012) who found that, replacing FM by shrimp head waste meal at $0,15,30,45$ and $60 \%$ in $30 \%$ protein diets decreased final $\mathrm{BW}$ and the decrease was more pronounced at the higher replacing levels. In another study, Hammoumi et al. (2008) found that replacement of $25,50,75$ or $100 \%$ of FM by SFB alone or mixed with soybean meal (1:1) significantly $(\mathrm{P}<0.05)$ decreased the final BW of Nile tilapia fed $28 \% \mathrm{CP}$ experimental diets.

Soltan and Tharwat (2006) incorporated fermented fish by-products silage in iso-nitrogenous $(30 \% \mathrm{CP})$ and isocaloric $(2600 \mathrm{Kcal} \mathrm{ME})$ diets for Nile tilapia, Oreochromis niloticus and African catfish, Clarias garipinus to replace $25,50,75$ or $100 \%$ of FM and they found that, dried SFB can successfully replace up to 25 and $50 \%$ of FM in tilapia and catfish diets, respectively without any significant loss in final $\mathrm{BW}$ while the higher replacing levels $(50,75$ or $100 \%$ for tilapia and 75 or $100 \%$ for catfish) significantly reduced the final BW for the two fish species. In another study, Soltan and El-Laithy (2008) evaluated the silage made from fish by-products and tomato and potato byproducts in isonitrogenous $(30 \%)$ and isocaloric $(2700$ Kcal ME) diets fed to Nile tilapia fish and they found that replacement of $30 \%$ of the dietary protein by silage did not significantly affected the final BW of Nile tilapia while the higher replacing levels (40 or $50 \%$ ) significantly reduced BW of Nile tilapia.

Weight gain (TWG) and specific growth rate (SGR):

Results of Table 2 indicated that, increasing level of substituting levels of FM by FFB up to $100 \%$ did not significantly affected TWG of Nile tilapia and the same trend was also observed for specific growth rate (SGR). Nwanna and Daramola (2001) found that, replacing FM by shrimp head waste meal at $0,15,30,45$ and $60 \%$ in $30 \%$ protein diets decreased final TWG and SGR and thedecrease was more pronounced at the higher replacement levels. In another study, Wassef et al. (2003) found that replacement of $25,50,75$ or $100 \%$ of FM by FFB alone or mixed with soybean meal $(1: 1)$ did not significantly affected WG and SGR of Nile tilapia by the partial or the complete replacement of SFB alone or when mixed with soybean meal Similar results were obtained by Soltan and Tharwat (2006) who indicated that dried SFB can successfully replace up to 25 and $50 \%$ of FM 


\section{Gouda, A.H. et al.}

in tilapia and catfish diets, respectively without any negative significant effect in WG or SGR while the highest replacing levels $(50,75$ or $100 \%$ for tilapia and 75 or $100 \%$ for catfish) significantly reduced the WG and for the two fish species. In another study, Soltan and El-Laithy (2008) evaluated the silage made from fish byproducts, tomato and potato by-products in isonitrogenous (30\%) and isocaloric (2700 Kcal ME) diets fed to Nile tilapia fish and found that replacement of $30 \%$ of the dietary protein by silage did not significantly affecte the TWG or SGR of Nile tilapia fish while the higher replacing levels (40 or $50 \%$ ) significantly reduced TWG of Nile tilapia.

The present study showed that SFB possessed adequate nutritional value for Nile tilapia fish at low inclusion levels, making possible substitution level of up to $50 \%$ of fish meal protein without adverse effect on growth performance of Nile tilapia.

The superior performance of control fish group fed the diet SFB0 was referred to the fact that the nutritional value of FM-protein approximating almost exactly to the nutritional requirements of cultured finfish species (Tacon, 1993). When $25 \%$ or $50 \%$ of FM protein was replaced by SFB protein did not followed by significant effect on all growth parameters (BW, BL, TWG and SGR) while the higher replacing levels (75 or $100 \%$ ) significantly adversed these parameters. Soltan and Tharwat (2006) showed that FM contained comparatively higher total indispensable amino acid (IAA) content (45.50\%) than SFB (33.37\%) and the IAA of SFB did not cover the requirements of Nile tilapia from these amino acids. Therefore, the higher replacing levels of FM by FFB (50, 75 or $100 \%)$ significantly reduced all growth performance parameters of Nile tilapia (Table 2).

The higher levels ( $50 \%$ FM replacement by FFB) were reported in earlier reports of Lapie and BiguerasBenitez (1992) who found no differences in growth performance of Nile tilapia fed a formic acid preserved fish silage blended with FM (1:1), and growth performance was significantly reduced when

the replacing levels increased up to $75 \%$. Also, Fagbenro (1994) and Fagbenro and Jauncy, (1994) stated that, up to $75 \%$ of FM protein could be successfully replaced with tilapia silage and soybean meal (1:1) in 30\% CP diets for all male O. niloticus.

Feed conversion ratio:

Table 3 showed that FCR values were found to be $2.11,2.22,2.34,2.47$ and 2.54 for fish groups fed the different experimental diets, SFB0, SFB25, SFB50, FFB75 and SFB100, respectively and the differences were significant $(\mathrm{P}<0.05)$.

Table (2): Growth performance for Nile tilapia fengerlings fed graded levels of FSB (w \pm SE).

\begin{tabular}{|c|c|c|c|c|c|}
\hline \multirow[b]{2}{*}{ Parameters } & \multicolumn{3}{|c|}{ Replacement rate } & \multirow[b]{2}{*}{$75 \%$} & \multirow[b]{2}{*}{$100 \%$} \\
\hline & $0 \%$ & $25 \%$ & $50 \%$ & & \\
\hline initial Wg/fish & $5.87 \pm 0.11$ & $5.82 \pm 0.11$ & $5.82 \pm 0.1$ & $5.77 \pm 0.11$ & $5.80 \pm 0.11$ \\
\hline $\begin{array}{l}\text { Final } \\
\mathrm{Wg} / \text { fish }\end{array}$ & $55.80 \pm 0.92 \mathrm{a}$ & $49.83 b \pm 0.92$ & $48.90 \mathrm{~b} \pm 0.92$ & $44.42 \mathrm{c} \pm 0.92$ & $42.18 \mathrm{~d} \pm 0.92$ \\
\hline initial L & $6.49 \pm 0.13$ & $6.31 \pm 0.13$ & $6.13 \pm 0.13$ & $6.31 \pm 0.13$ & $6.28 \pm 0.13$ \\
\hline Final L & $13.83 \mathrm{a} \pm 0.6$ & $13.77 \mathrm{~b} \pm 0.6$ & $13.86 \mathrm{~b} \pm 0.6$ & $13.33 b \pm 0.6$ & $13.14 b \pm 0.6$ \\
\hline DWG g/fish & $0.42 \mathrm{a} \pm 0.003$ & $0.37 \mathrm{~b} \pm 0.003$ & $0.36 \mathrm{~b} \pm 0.003$ & $0.40 \mathrm{c} \pm 0.003$ & $0.30 \mathrm{~d} \pm 0.003$ \\
\hline TWG g/fish & 49.93 & 44.01 & 43.08 & 38.65 & 36.38 \\
\hline SGR & 1.87 & 1.79 & 1.77 & 1.70 & 1.65 \\
\hline $\mathrm{k}$ & $2.27 \mathrm{a} \pm 0.02$ & $1.97 \mathrm{a} \pm 0.02$ & $1.85 \mathrm{ab} \pm 0.02$ & $1.83 \mathrm{~b} \pm 0.02$ & $1.76 \mathrm{ab} \pm 0.02$ \\
\hline
\end{tabular}

a-b: means in the some row superscreteted with different letters significantly differed at $\mathrm{P}<0.05$.

Table 3: Feed utilization for Nile tilapia fed graded levels of FSB.

\begin{tabular}{|c|c|c|c|c|}
\hline $\begin{array}{l}\text { Replacement } \\
\text { rate }\end{array}$ & FI g/fish & FCR & PER & SR\% \\
\hline $0 \%$ & 105.35 & 2.11 & 0.77 & 100 \\
\hline $25 \%$ & 97.70 & 2.22 & 0.67 & 100 \\
\hline $50 \%$ & 100.80 & 2.34 & 0.68 & 100 \\
\hline $75 \%$ & 95.46 & 2.47 & 0.62 & 100 \\
\hline $100 \%$ & 92.40 & 2.54 & 0.59 & 100 \\
\hline
\end{tabular}


The best FCR was recorded for fish fed the diet SFB Soltan and Tharwat (2006) found that the best FCR and PER were recorded for fish fed the diet FFB25 where $25 \%$ of FM protein was replaced by FFB protein and did not significantly differe from those obtained for fish group fed the control diet (FFB0). The higher replacing levels of FM by FFB (50, 75 or $100 \%)$ significantly $(\mathrm{P}<0.001)$ adversed FCR for Nile tilapia. Fagbenro and Bello-Olusoji (1997), Fagbenro (1994) and Jatomes et al. (2002) found that, the best FCR was recorded for Nile tilapia fish fed diets contained 0,10 and $15 \%$ shrimp head silage as a replacement to fish meal and the worst FCR was obtained by the higher replacing levels (20, 25 and $30 \%$ ). On the other hand, Lapie and Bigueras-Benitez (1992) found no difference in feed efficiency between $O$. niloticus fed a formic acid preserved fish silage blended with FM (1:1) or a FM-based diet. In another study, Wassef et al. (2003) found that, partial or total replacement of FM by FFB alone or mixed with soybean meal did not significantly affected FCR. Stone et al. (1989) studied the apparent digestibility and utilization of fish protein subjected to the ensilaging process, comparing with fish meal in dry diets fed to rainbow trout (Salmo qairdneri). They reported that digestibility values were higher for the fish silage than for fish meal, the fish silages were not as efficiently utilized for growth. Whole fish and fish processing wastes were found to be equivalent sources of nitrogen provided the degree of autolysis was the same and the diets were other wise nutritionally balanced.

\section{Protein efficiency ratio (PER):}

Results of PER of tilapia fed the different experimental diets are summarized in table 3. As described in this table, the average PER for fish groups fed the experimental diets ranged between 0.59 and 0.77 and the lowest value was observed for fish group fed the diet SFB100 where $100 \%$ of FM was replaced by SFB. Hardy et al., (1984) reported that PER of rainbow trout fed fish silage at levels of $12.5,25$ and $50 \%$ were 1.69 , 1.61 and 1.66, respectively.

Fagbenro and Bello-Olusoji (1997), Fagbenro (1994) and Jatomes et al. (2002) found that the higher PPR was recorded for Nile tilapia fish fed diets contained 0,10 and $15 \%$ shrimp head silage as a replacement to fish meal and the worst PER was obtained the higher replacing levels (20, 25 and 30\%). In another study Soltan and Tharwat (2006) stated that the best PER were recorded for fish fed the diet FFB25 where $25 \%$ of FM protein was replaced by SFB protein and did not significantly different from those obtained for fish group fed the control diet (SFB0) and The higher replacing levels of FM by SFB $(50,75$ or $100 \%)$ significantly $(\mathrm{P}<0.001)$ adversed PER. On the other hand, Wassef et al., (2003) found that, partial or total replacement of FM by SFB alone or mixed with soybean meal did not significantly affected PER.

This improvement in growth performance for fish fed SFB was possibly due to their higher palatability and preference of the fish to take it as their potential food, (Sammader et al., 2011). Another potential advantage of using silage rather than meal in aquaculture diets is the fact that most of the silage processes used to date do not involve heat denaturation of the proteins, (Nwanna, 2013).

Proximate analysis of whole fish:

The proximate analysis of tilapia as affected by replacing levels of FM by FFB in the diets outlined in Table 4. As described in this table, moisture ranged between 77.40 and $80.55 \%$; crude protein 61.70 and 64.44\%; ether extract ranged between 15.50 and 17.73 and ash from 17.84 to $22.43 \%$ and the differences among the different experimental fish groups were significant.

As compared to control group (FFB0), all replacing levels of FM by FFB significantly $(\mathrm{P}<0.05)$ increased ash content of whole fish bodies control group and these results may be due to the high ash content of fish wastes used in preparation of FFB and these results were relatively similar to those obtained by Wassef et al. (2003) who found that, replacing of FM by FFB up to $75 \%$ did not significantly affected protein content of tilapia bodies. In recent study, Cavalheiro et al. (2007) substituted fish meal by fermented shrimp industry wastes at a substituting levels of $0,33.3,66.6$ and $100 \%$ in the diets of Nile tilapia, O. niloticus and they found that, the partial or complete replacement of FM by fermented shrimp industry wastes did not show any appreciable variation for the dry matter and protein content of fish. Soltan and Tharwat (2006) found that increasing replacing levels of FM by FFB in Nile tilapia diets decreased DM content in the whole body and the differences between fish groups were not significant and increasing FFB levels in tilapia diets up to $50 \%$ as a substitute of FM did not significantly affect protein content in whole body while the higher replacing levels ( 75 or $100 \%$ ) significantly increased protein content of whole body. They also added that partial or total replacement of FFB by FM did not significantly affected EE content of tilapia fish.

Soltan et a., (2008) found that DM of catfish did not significantly affected by all replacing levels of FM by SFB $(25,50,74$ and 100\%) and the same trend was also observed for ash content of whole fish bodies and they added that compared to control fish group, all replacing levels of FM by FFB significantly $(\mathrm{P}<0.001)$ decreased protein and $\mathrm{EE}$ content whereas fish group fed the control diet (FFB0) gained the highest protein and EE contents. Silage has also been used successfully as a low cost ingredient in aquaculture diets (Wassef et al.2003).

The image of fish as a healthy food is the main reason for increasing demand for fish meat but there are serious safety concerns related to the presence of parasitic hazards in fish meat.

\section{Economic efficiency for Nile Tilapia fed graded levels of FSB:}

Yet, $100 \%$ replacement was the economic treatment, but $25 \%$ replacement was economically similar to the control ( Table 5).

The larvae were thin, elongated up to $30 \mathrm{~mm}$, without segmentation, the mouth was surrounded with three lips with marked projections and having pointed tail without reproductive system in such larval stage. Based on 


\section{Gouda, A.H. et al.}

the morphological and parasitological findings, the isolated parasites were belonged to order Ascaridida and family Contacaecum. This met the description recorded by Lom and Dykova (1992) and Woo (1995). Moreover, Moa, (2010) mentioned that the importance of internal parasitic infestation as it affects health, palatability, productivity, marketability and aesthetic value of fish as the larvae may reach up to 8-10larvae per fish.

Clinical, postmortem and microscopical examination of fish

Examination of such important economic fish seemed apparently healthy except the group fed the diet FFB100\% started showing slight abdominal bulging with reddish swollen inflammation of the vent (Figure 1). Fish seemed of lower body weight compared to the other groups. While internal examinations showed many larvae on the abdominal musculature, body cavity, liver, heart, intestine and in severe infestations for all the internal structure of fish were found (figure, 2 and 3). These findings were similar to that was reported by Schaperclaus, (1992). Emaciation may be due to the feeding of larvae on host tissues and lowering liver fat content seriously reduced by such parasitism which leads to a weight decrease in affected fish; this explanation was reported by Abollo et al (2001).

Table (4): The proximate analysis (\% DM basis) for Nile tilapia fed graded levels of SFB.

\begin{tabular}{lccccc}
\hline \multicolumn{5}{c}{ Replacement rates } \\
Parameter & $0 \%$ & $25 \%$ & $50 \%$ & $75 \%$ & $100 \%$ \\
\hline Dry matter & $20.77 \pm 1.29$ & $22.57 \pm 1.29$ & $19.45 \pm 1.29$ & $20.71 \pm 1.29$ & $22.6 \pm 1.29$ \\
Protein & $64.44 \mathrm{a} \pm 0.42$ & $63.28 \mathrm{ab} \pm 0.42$ & $63.59 \mathrm{ab} \pm 0.42$ & $61.97 \mathrm{~b} \pm 0.42$ & $61.7 \mathrm{~b} \pm 0.42$ \\
Fat & $17.73 \mathrm{a} \pm 0.18$ & $16.65 \mathrm{~b} \pm 0.18$ & $16.20 \mathrm{~b} \pm 0.18$ & $15.84 \mathrm{bc} \pm 0.18$ & $15.50 \mathrm{c} \pm 0.18$ \\
Ash & $17.84 \mathrm{~b} \pm 0.58$ & $18.93 \mathrm{~b} \pm 0.58$ & $22.43 \mathrm{a} \pm 0.58$ & $18.69 \mathrm{~b} \pm 0.58$ & $18.95 \mathrm{~b} \pm 0.58$ \\
\hline
\end{tabular}

Averages within each row having different letters are significantly different $(\mathrm{P}<0.05)$,

Table 5: the economic efficiency for Nile Tilapia fed graded levels of FSB.

\begin{tabular}{lcccc}
\hline Treatments & $\begin{array}{c}\text { Feed intake } \\
\text { g/fish }\end{array}$ & $\begin{array}{c}\text { Cost (LE)/ } \\
\text { ton ration }\end{array}$ & $\begin{array}{c}\text { Total gain } \\
\text { g/fish }\end{array}$ & $\begin{array}{c}\text { Feed Cost (LE)/ } \\
\text { kg gain }\end{array}$ \\
\hline $0 \%$ & 105.35 & 4500 & 49.93 & 9.49 \\
$25 \%$ & 97.70 & 4273 & 44.01 & 9.48 \\
$50 \%$ & 100.80 & 3940 & 43.08 & 9.21 \\
$75 \%$ & 95.46 & 3698 & 38.65 & 9.13 \\
$100 \%$ & 92.40 & 3325 & 36.38 & 8.44 \\
\hline
\end{tabular}

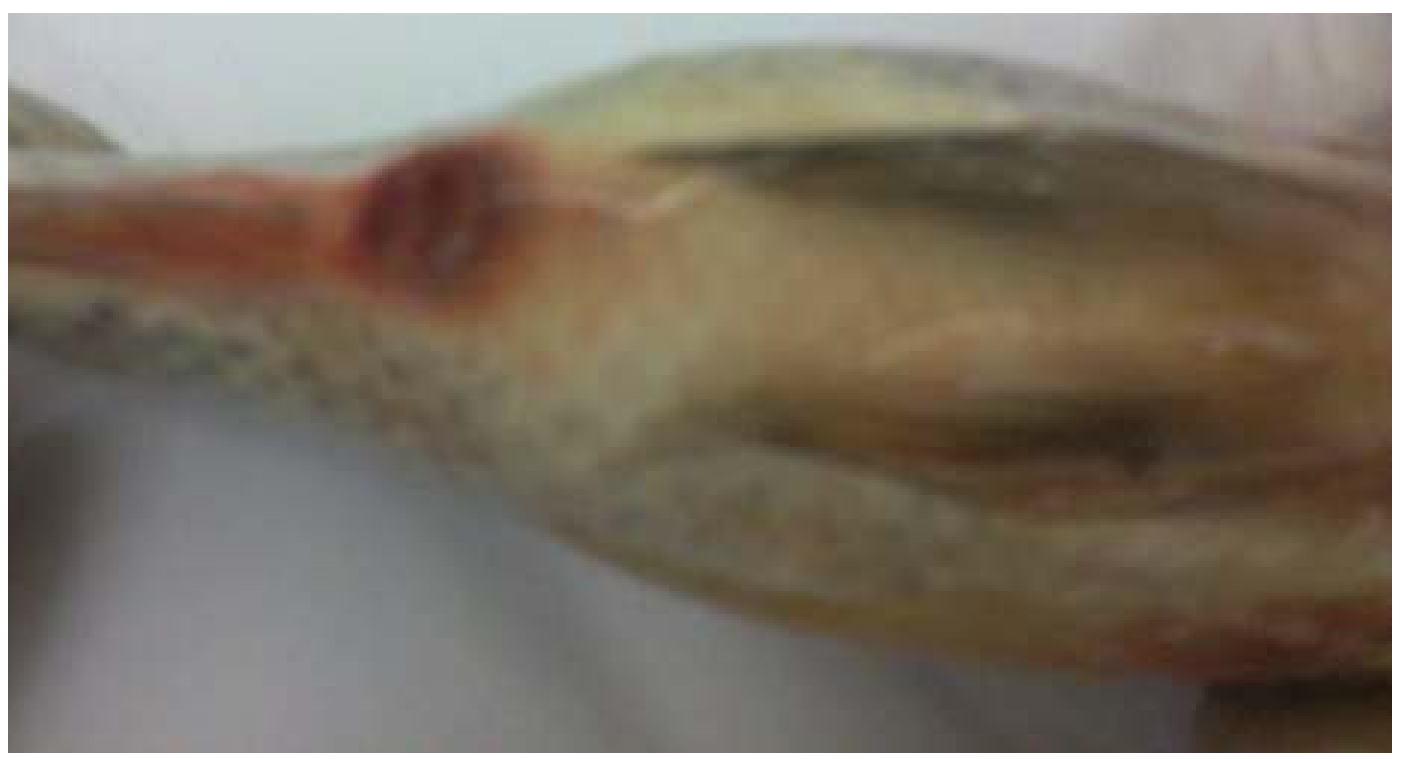

Figure 1: Slight abdominal bulging with reddish swollen inflammation of the vent from the group fed the diet FFB100\%. 


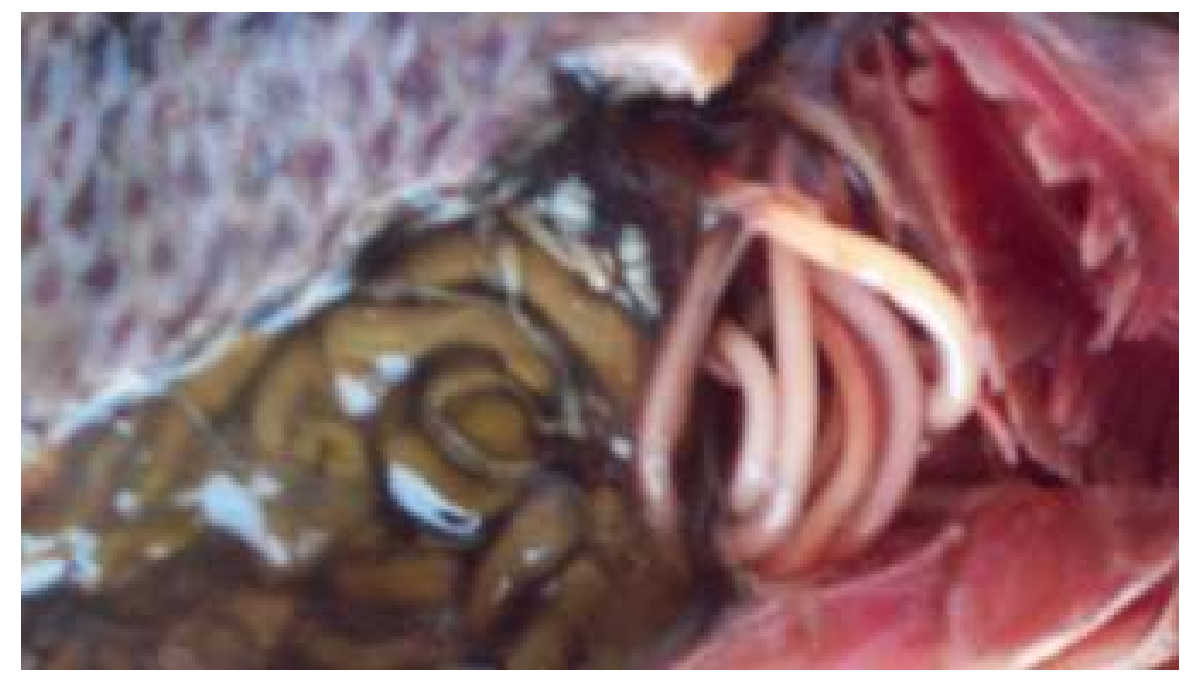

Figure 2: larvae on the heart of fish from the group fed the diet FFB100\%.

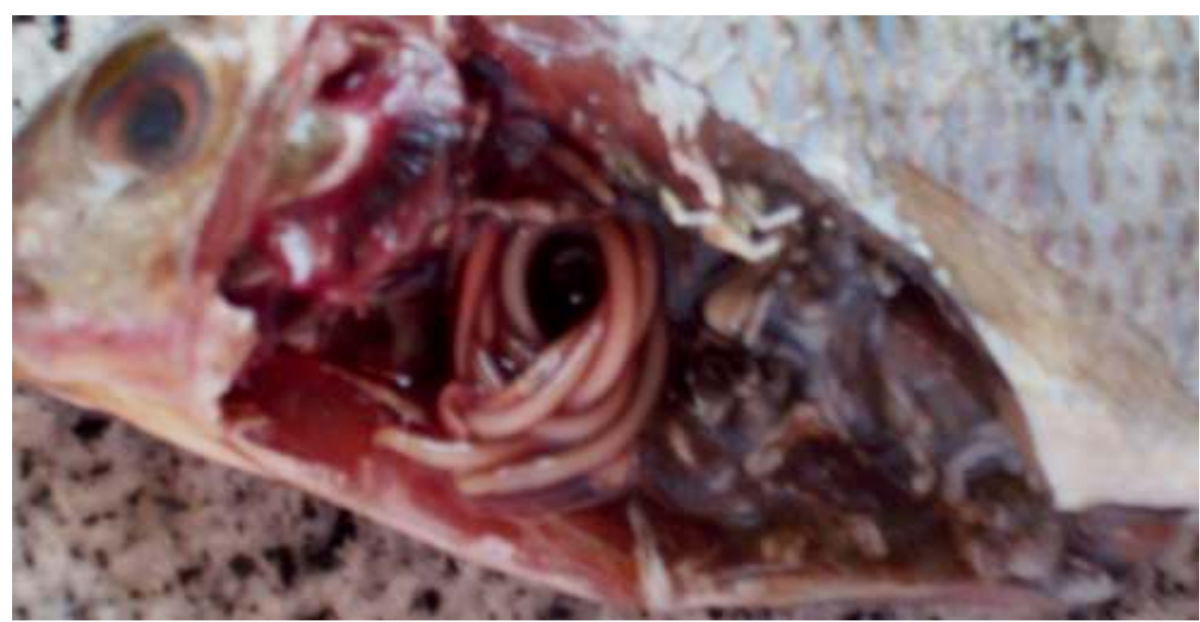

Figure 3: Severe infestations for all the internal structure of fish fed the diet FFB100\%.

\section{REFERENCES}

Abollo, E., Gestal, C. and Pascual, S. (2001). Anisakis infestation in marine fish and cephalopods from Galician waters. Área de Parasitología, Facultad de Ciencias, Universidad de Vigo, Aptdo. 87436200 Vigo, Spain.

AOAC (1990): Association of Official Analytical Chemists, Official Methods of Analysis. Washington, D. C.

Bairagi A., Sarkar Ghosh K., Sen S.K., and Ray A.K. (2012). Duckweed (Lemna polyrhiza) leaf meal as a source of feedstuff in formulated diets for rohu (Labeo rohita Ham.) fingerlings after fermentation with a fish intestine bacterium. Biores. Technol., 85: 17-24.

Berland, B. (1989). Identification of larval nematodcs from fish. In nematode problems in North Atlantic fish. Report from a workshop in Kiel, 34 April 1989. Int. Con. For the exploration of sea 16-22.
Boyd, D. (1979): Water Quality in Warmwater Fish Ponds. Auburn University Agricultural Experiment Station, Auburn, AL.

Cavalheiro, J. M. O., Oliveira de Souza, E. and Bora, P. S. (2007). Utilization of shrimp industry waste in the formulation of tilapia (Oreochromis niloticus Linnaeus) feed. Bioresource Technology, 98:602606.

Collins, R. A. and Delmendo, M. N. (1979). Comparative economics of aquaculture in cages, raceways and enclosures. In: Advance in aquaculture, England, Fishing News Books.

De-Silva, S. S. and Anderson, T. A. (1995): Fish nutrition in aquaculture. CHAPMAN edaw\& HALL, London.

Duncan, D. B. (1955): Multiple range and Multiple test. Biometerics, 11: 1-42.

Esteban M.B., Gracia A.J., Ramos P.,and Mcrquez M.C. (2007). Evaluation of fruit-vegetable and fish wastes as alternative feedstuFFB in pig diets. Waste Management. 27: 193-200. 
Fao,1983: fish feeds and feeding in, developing countries UNDP/FAO,ACDP/REP/1897 PP.

Fagbenro, O. A. (1994): Dried fermented fish silage in diets for Oreochromis niloticus. Israeli J. Aquacult., Bamidgeh, 46(3):140-147.

Fagbenro, O. A. and Jauncey, K. (1994). Chemical and nutritional quality of dried fermented fish silage and their nutritive value for tilapia (Oreochromis niloticus). Animal Feed Sci., Technol., 45:167176.

Fagbenro, O. A. and Bello-Olusoii, O. A. (1997).: Preparation, nutrient composition and digestibility of fermented shrimp head silage. Food Chemistry, 60:489-493.

Fagbenro O.A., Jauncey K. (2012). Growth and protein utilization by juvenile catfish (Clarias gariepinus) fed dry diets containing co-dried lactic acid-fermented fish silage and protein feedstuFFB. Bioresource Technology. 51: 29-35.

Green, B. W. (1992): Substitution of organic manure for pelleted feed in tilapia production. Aquaculture, 101:213-222.

Hammoumi A., Faid M., Yachioui H., Amarouch H. (2008). Characterization of fermented fish waste used in feeding trials with broilers. Process Biochemistry.32: 423-427.

Hardy, R.W.; Shearer, K.D. and Spinelli, J. (1984): The Nutritional properties of Co- dries fish silage in rainbow trout (Salmo gairdneri) dry diets. Aquaculture 38, 35- 44.

Jackson, A.J.; Kerr, A.K. and Bullock, A.M. (1984): Fish silage as a dietary ingredient for salmon. II. Preliminary growth findings and nutritional pathology. Aquaculture 40, 283-291.

Jatomes, M. P., Novoa, M. A. O., Figueroa, J. L. A., Hall, G. M. and Shirai, K. (2002): Feasibility of fishmeal replacement by shrimp head silage protein hydrolysate in Nile tilapia (Oreochromis niloticus L) diets. J. Sci. Food Agric., 82:753759.

Kompiang, I.P.; Arifudin, R. and Raa, J. (1980 a): In "Advances in fish science and technology" (J.J. Connell. ed.), pp. 349-352. Fishing News Book. Ltd- London.

Kompiang, I.P.; Darwanto, A. and Arifuddin, R. (1980 b): Nutritional value of fish silage. In: J.G. Disney and D. James (editors), fish silage production and its use. F.A.O Fish. Rep. No. 230 pp. 44-47.

Kompiang, I.P.; Yashadi T. and Cresswell, D.C. (1980 c): In" Fish silage production and its use" (J.C. Disney and D. James, eds.) pp 38-43. FAO fish Repy No. 230.

Lapie, L. P. and Bigueras-Benitez, C. M. (1992): Feeding studies on tilapia (Oreochromis niloticus) using fish silage. pp. 165-177 In: D. James (ed.) FAO Fish Rep., No. 470, FAO, Rome.

Lom, J. and Dykova, I. (1992).Developments in aquaculture and fisheries science. $1^{\text {st }}$ edn . (Ed. by Lom, J. and Dykova, I.,) Elsevier Amsterdam, London, NY, Tokyo.
Moa, M. (2010). Prevalence of Contracecum spp. in Tilapia in Lake Tana,

Bahir Dar, Ethiopia. Unpublished DVM thesis, Faculty of Veterinary Medicine,University of Gondar, Ethiopia.

Meyer, C. M. and Olson, W.C. (1992): Essentials of parasitology. W.M.C. Brown publishers, 5th Ed. IA, USA.

Mondal K., Kaviraj A., Mukhopadhyay P.K., Datta M.,and Sengupta C., (2007). Evaluation of fermented fish-offal in formulated diet of the Indian major carp, rohu, Labeo rohita (Hamilton). Acta Ichthyologica et Piscatoria. 37: 99-105.

Norman, C.A.; Silverside, D.; Hector, D.A. and Francis, S. (1979): Fish silage, Trop. Sci. 21, 221-230.

NRC (2011): Nutrient requirement of fish. National Academy Press, Washington D.C.

Nwanna, L. C. and Daramola, J. A. (2001): Harnessing of shrimp head waste in Nigeria for low cost production of tilapia. Pakistan, J. of Nutrition 2 (6):339-345.

Nwanna L.C. (2013). Nutritional value and digestibility of fermented shrimp head waste meal by African catfish Clarias gariepinus. Pakistan Journal of Nutrition. 2: 339-345.

Raa, J. and Gildberg. A. (1982): Fish silage: A review. CRC (Critical Reviews in Food Science and Nutrition 1982), 383-419.

Rangacharyulu R.V., Giri S.S., Paul, B.N.,Yashoda K.P., JagannathaRao R., Mahendrakar N.S., Mohanty S.N., and Mukhopadhyay P.K. (2013). Utilization of fermented silkworm pupae silage in feed for carps. Bioresource Technology.86: 2932.

Rungruangsak, K. and Utne, F. (1981). Effect of different acidified wet feed on protease activities in the digestive tract and on growth rate of rainbow trout (Salmo gairdneri richordson) Aquaculture 22: 67- 79.

SAS (1996): SAS Procedure Guide "version 6.12 Ed". SAS Institute Inc., Cary, NC, USA.

Samaddar A., Mondal K., and Kaviraj A. (2011) Evaluation of Fermented Mixture Containing Fish Offal Meal in Compound Diets for the Freshwater Catfish Mystus vittatus (Bloch). Proc Zool Soc. 64: 117-123.

Schaperclaus, W. (1992). Fish diseases Vol. 2. 5th corrected, revised and substantially enlarged edition.

Soltan, M. A. and El-Laithy, S. M. M. (2008): Evaluation of fermented silage made from fish, tomato and potato by-products as a feed ingredient for Nile tilapia, Oreochromis niloticus. Egypt. J. Aquat. Biol. \& Fish., 12(1):25-41.

Soltan, M. A. and Tharwat, A. A. (2006): Use of fish silage for partial or complete replacement of fish meal in diets of Nile tilapia, Oreochromis niloticus and African catfish, Claris gariepinus. Egyptian J. Nutrition and Feeds, 9(2):299-314. 
Soltan, M. A., Hanafy, M. A. and Wafa, M. I. A. (2008): An Evaluation of Fermented Silage Made from Fish By-Products As A Feed Ingredient for African Catfish (Clarias gariepinus). Global Veterinaria, 2(2):80-86.

Stone, F. E.; Hardy, R.W.; Shearer, K.D. and Scott, T. M. (1989): Utilization of fish silage by rainbow trout (Salmo Gairdneri). Aquaculture, 76, 109. 118.

Stoskopf, M. K. (1993): Fish medicine. W. B. Saunders Co. Philadelphia, Pennsylvania, 19106, USA.

Tacon, A. G. J. (1993): Feed ingredients for warm-water fish: fish meal and other processed feedstuSFB. FAO Fisheries Circular No. 856. FAO, Rome.
Wassef, E. A., Sweilam, M. A. and Attalah, R. F. (2003): The use of fermented fish silage as a replacement for fish meal in Nile tilapia (Oreochromis niloticus) diets. Egypt. J. Nut. Feed, 6 (Special Issue):357-370.

Woo, P. T. K. 1995: Fish diseases and disorders, Vol. 1: Protozoan and Metazoan infections. C. A. B. International, St. Albans, U.K., 808.

Yegorov Y.E., Terekhov S.M., and Vishnyakova K.S.. (2013). Telomerization as a method of obtaining immortal human cells preserving normal properties. Ontogenez, 34: 183-192. [Article in Russian].

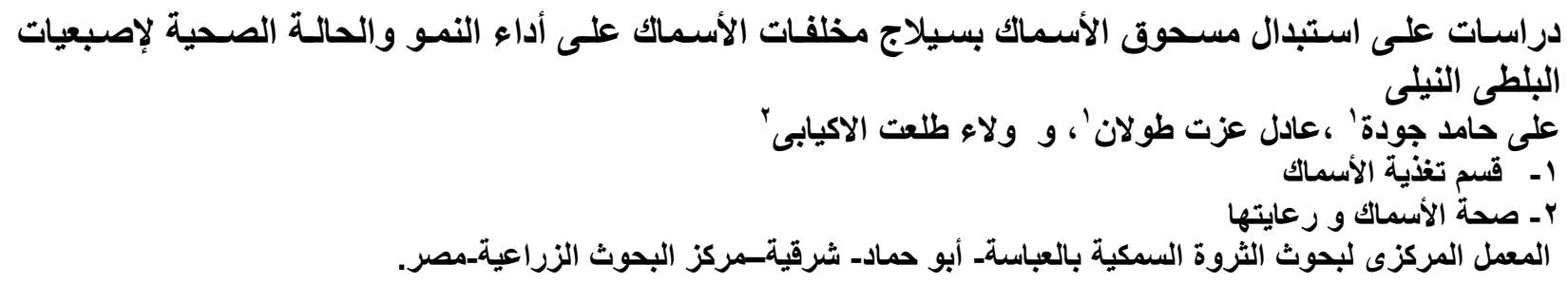

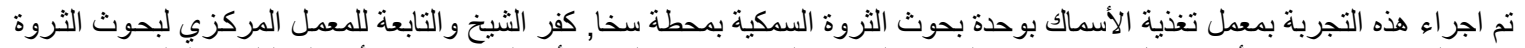

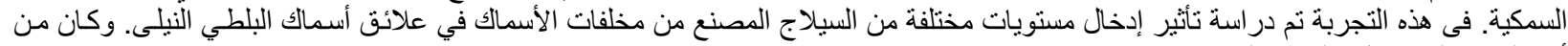

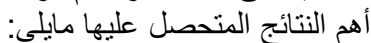

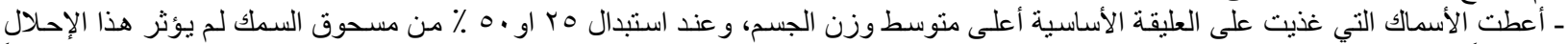

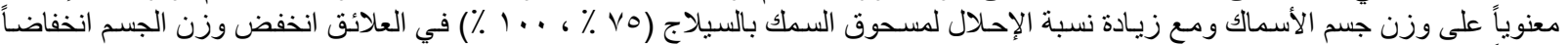
معنوياً مقارنة بمجمو عزئة الكنترول (المقارنة).

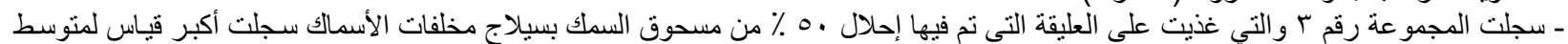

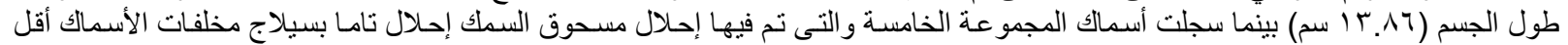

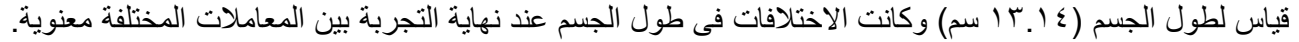

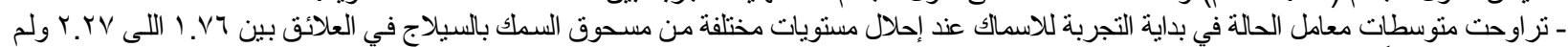

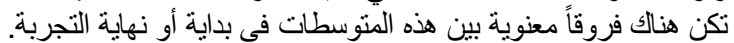

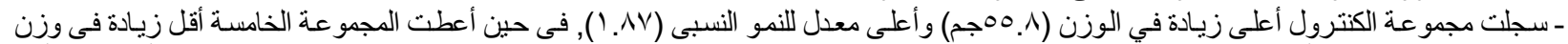

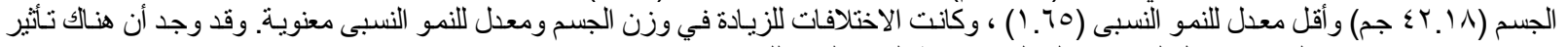

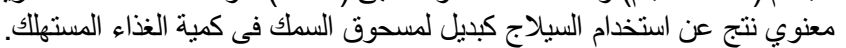

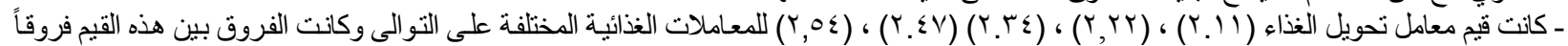
غير معنوية، كما تراوحت قيم الكفاءة النسبية للبروتين ما بين.

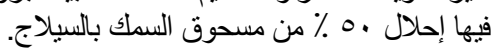

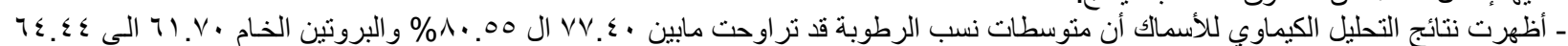

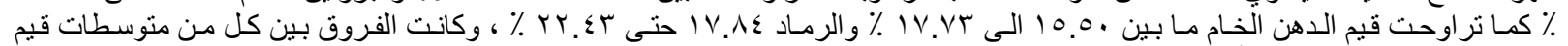
البروتين و الدهن والرماد فيماد فروقاً معنوية.

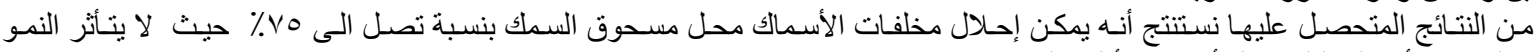

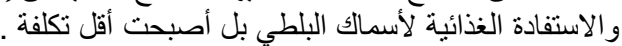

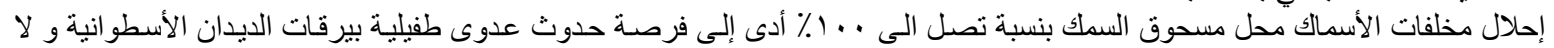

